\title{
Generation of T cells from Human and Nonhuman Primate Pluripotent Stem Cells \\ Akhilesh Kumar ${ }^{1}$, Saritha S. D'Souza ${ }^{1}$, Gene Uenishi' ${ }^{1}$ Mi Ae Park ${ }^{1}$ \\ Jeong Hee Lee ${ }^{1}$ and Igor I. Slukvin ${ }^{1,2,3, *}$
}

\begin{abstract}
${ }^{1}$ Wisconsin National Primate Research Center, University of Wisconsin, Madison, WI 53715, USA; ${ }^{2}$ Department of Cell and Regenerative Biology, School of Medicine and Public Health, University of Wisconsin, Madison, WI 53707, USA; ${ }^{3}$ Department of Pathology and Laboratory Medicine, University of Wisconsin, Madison, WI 53792, USA

*For correspondence: islukvin@wisc.edu
\end{abstract}

[Abstract] Pluripotent stem cells (PSCs) have the potential to provide homogeneous cell populations of $T$ cells that can be grown at a clinical scale and genetically engineered to meet specific clinical needs. OP9-DLL4, a stromal line ectopically expressing the Notch ligand Delta-like 4 (DLL4) is used to support differentiation of PSCs to T-lymphocytes. This article outlines several protocols related to generation of T cells from human and non-human primate (NHP) PSCs, including initial hematopoietic differentiation of PSC on OP9 feeders or defined conditions, followed by coculture of the OP9-DLL4 cells with the PSC-derived hematopoietic progenitors (HPs), leading to efficient differentiation to T lymphocytes. In addition, we describe a protocol for robust T cell generation from hPSCs conditionally expressing ETS1. The presented protocols provide a platform for $\mathrm{T}$ cell production for disease modeling and evaluating their use for immunotherapy in large animal models.

Keywords: Human pluripotent stem cells, Human embryonic stem cells, Non-human primate pluripotent stem cells, Hemogenic endothelium, Hematopoietic progenitor, T cells, Hematopoietic differentiation

[Background] T lymphocyte ( $T$ cells) play a key role in cell-mediated immune responses and are involved in monitoring and killing tumor cells. Throughout the last decades, several strategies have been developed to redirect, culture and/or enhance T lymphocytes against cancer (Houot et al., 2015; June et al., 2018) and utilize them for T cell-based adoptive immunotherapies. Recent clinical trials have shown outstanding outcomes in relapsed and refractory lymphoma patients treated with chimeric antigen receptor (CAR)-T cells (Riviere and Sadelain, 2017).

Human pluripotent stem cells (hPSCs), including embryonic (hESCs) and induced (hiPSCs), provide a promising resource to produce $T$ cells for adoptive cellular immunotherapies, which can be coupled with genetic engineering technologies to generate off-the-shelf supplies of CAR T cells. In addition, generating hPSCs from antigen (Ag)-specific cytotoxic T lymphocytes (CTLs) and redifferentiating them into functional CTLs could enable the scalable production of rejuvenated CTLs (Minagawa and Kaneko, 2014; Kaneko, 2016). Several reports have demonstrated T cell generation from hPSCs (Nishimura et al., 2013; Vizcardo et al., 2013) and the feasibility of hiPSC based CAR T cell therapies (Themeli et al., 2013). However, there is still a need to improve the efficacy of T cell generation and expansion from hPSCs. In addition, further advances in hPSC-based T cell therapies will require their preclinical 
evaluation in large animal models. Since macaques are physiologically and immunologically similar to humans, including possessing orthologous MHC genes (Adams et al., 2001), and similarities in killer cell immunoglobulin-like receptors (KIR) with humans (Bimber et al., 2008; Parham et al., 2010), nonhuman primates (NHPs) will be the most appropriate model to address the therapeutic efficacy, safety and immunogenicity of PSC-derived T cells.

Here, we describe an improved method for the derivation of T cells from human and NHP-PSCs with a higher efficiency and shorter time (as soon as 3 weeks) than existing protocols. Differentiation of T cells from hPSCs involves two major steps: induction of hematopoietic progenitor cells (HPs) from hPSCs and their subsequent differentiation into T cells. Our lab previously reported well-established protocols on the induction of hematopoietic lineages from hPSCs on OP9 feeders and in defined feederand serum-free conditions (Vodyanik et al., 2005; Vodyanik and Slukvin, 2007; Uenishi et al., 2014). We showed that hemogenic progenitors from different stages of differentiation or different sources were cocultured on OP9-DLL4 to differentiate into T cells (Kumar et al., 2019b). We have also reported a protocol for the induction of hematopoietic lineages from NHP-PSCs (D'Souza et al., 2016). T cells differentiation from both hPSCs or NHP-PSCs proceeds through a $\mathrm{CD} 5^{+} \mathrm{CD} 7^{+}$progenitor stage that eventually transitions into $\mathrm{CD} 8^{+} \mathrm{CD} 4^{+}$double-positive cells. Altogether, the protocol used for the PSCderived $\mathrm{T}$ cells presents a platform for $\mathrm{T}$ cell production to evaluate their utility for adoptive immunotherapies and preclinical testing in large animal models.

\section{Related Information}

\section{Hematopoietic differentiation from human PSCs in an OP9 co-culture system}

Hematopoietic differentiation of hPSCs on mouse stromal OP9 feeders is performed in serum-containing medium without addition of any cytokines (Vodyanik et al., 2005). In this system, hPSCs undergo stepwise progression toward APLNR ${ }^{+} P D G F R \alpha^{+}$primitive posterior mesoderm with hemangioblast colony forming cells (HB-CFCs) that reflects primitive hematopoiesis, KDR ${ }^{\text {hiPDGFRalo/-VEC- }}$ hematovascular mesodermal progenitors with definitive hematopoietic potential, immature VE-cadherin $(V E C)^{+} C D 43^{-}$CD73- HE, which specify into DLL4 ${ }^{+}$arterial hemogenic endothelium (HE) with definitive hematopoietic potential, and DLL4- non-arterial-type HE with mostly primitive hematopoietic potential; and $\mathrm{CD} 34^{+} \mathrm{CD} 43^{+}$hematopoietic progenitors (HPs) that include $\mathrm{CD} 43^{+} \mathrm{CD} 235 \mathrm{a}^{+} \mathrm{CD} 45^{+/-} \mathrm{HPs}$, enriched in erythromegakryocytic progenitors and $\mathrm{CD}^{2} 3^{+} \mathrm{CD} 235 \mathrm{a} / 41 \mathrm{a}^{-}$multipotent HPs with a lin CD34 ${ }^{+} \mathrm{CD} 90^{+} \mathrm{CD} 38^{-} \mathrm{CD} 45 \mathrm{RA}^{-}$hematopoietic stem progenitor cells phenotype, and lymphomyeloid potential (Vodyanik et al., 2006; Choi et al., 2009a and 2009b; Choi et al., 2012; Kumar et al., 2019a and 2019b; Uenishi et al., 2018) (Figure 1). CD43+ HPs generated in this coculture can be collected on days 8-9 of differentiation and subsequently cultured on OP9-DLL4 in lymphoid conditions to generate T cells (Kumar et al., 2019b). We also demonstrated that T cells can be generated directly from definitive hemogenic progenitors collected from earlier stages of development (hematovascular mesoderm or HE stage) and cultured in lymphoid conditions on OP9-DLL4 (Kumar et al., 2019b). 


\section{Hematopoietic differentiation from human PSCs in a chemically defined system}

We have reported defined feeder- and serum-free conditions for generation of blood from hPSCs in chemically defined conditions. In this differentiation system, hPSCs follow stages of development similar to those described in hPSCs cocultured on OP9 feeders, including the formation of VE-Cadherin ${ }^{+} \mathrm{CD} 73$ CD235a/CD43- HE and CD34 ${ }^{+} \mathrm{CD} 43^{+}$HPs with myeloid and T lymphoid potential (Uenishi et al., 2014) (Figure 1). We typically use collagen IV coated plates for differentiation in defined conditions to reduce cost. However, more expensive matrix Tenascin $C$ can be used instead of collagen IV to improve hematopoietic differentiation and promote development of HPs with T cell potential in defined conditions (Uenishi et al., 2014).

\section{Genetic engineering of Doxycycline-inducible iETS1 hPSCs}

We have recently reported a protocol for the generation of conditional gene expression of ETS1 under tetracycline responsive element (TRE) promoter along with M2rtTA (reverse tetracycline transactivator) introduced into hPSCs using PiggyBac transposons (Jung et al., 2016; Park et al., 2018a and 2018b). In one vector ETS1 is downstream from the TREtight promoter, along with the zeocin resistance gene driven by the EF1 a promoter, subcloned between the ends of 2 ITRs of the transposon vector. For easy detection of transgene expression upon addition of doxycycline to the culture, ETS1 is linked with Venus through a 2A self-cleaving peptide sequence. The second vector has the M2rtTA promoter linked with a puromycin resistance gene through a $2 A$ peptide sequence subcloned between the ends of 2 ITRs. Using 2 different antibiotic genes facilitates the selection of clones that incorporate both vectors in a single step. The use of a two-vector system allows flexibility to adjust the TRE/M2rtTA ratio to achieve robust doxycycline dependent gene expression in hPSCs while limiting transgene leakage. hPSCs are cultured and then transfected on matrigel plates in mTeSR1 medium. Single hPSC colonies can be picked up from low-density cultures of cell populations (Park et al., 2018a and 2018b).

\section{$T$ cell production from iETS1 hPSCs}

We have demonstrated that $\mathrm{T}$ cell production from hESCs can be increased through activation of the arterial program at the mesodermal stage of development by overexpression of the transcription factor ETS1. Hemogenic progenitors generated following induction of ETS1 were more than 100 -fold enriched in T cell precursors as compared to control (Park et al., 2018b). Doxycycline treatment of differentiation cultures from days 2 to 6 , enhances the generation of CD34+ HPs with lymphoid potential. HPs collected from day 9 of differentiation cultures in the presence of doxycycline can subsequently be differentiated into $T$ cells in coculture with OP9-DLL4. Although T cell cultures from DOX- and DOX+conditions generate a similar percentage of $\mathrm{CD} 5^{+} \mathrm{CD} 7^{+}$and $\mathrm{CD} 4^{+} \mathrm{CD} 8^{+} \mathrm{T}$ cells, total numbers of $\mathrm{T}$ lymphocytes produced per $10^{4} \mathrm{CD} 43^{+}$cells from DOX-treated cultures are dramatically (> 8-fold) greater.

\section{Hematopoietic differentiation of NHP-PSCs on OP9 coculture}

Although the defined serum and feeder-free differentiation system described above works well with hPSCs, it does not support efficient generation of $\mathrm{CD} 34^{+} \mathrm{CD} 43^{+} \mathrm{HPs}$ with $\mathrm{T}$ cell potential from NHP- 
PSCs. That is why we recommend to culture on OP9 feeders to induce efficient production of lymphoid progenitors from NHP-PSCs. OP9 coculture supports blood production from different NHP species, including ESCs and iPSCs derived from rhesus and cynomolgus macaques. However, in contrast to human PSCs, NHP-PCS/OP9 cocultures require addition of GSK3 $\beta$ inhibitor and VEGF to promote hemogenic mesoderm development and human hematopoietic cytokines to support blood development (D'Souza et al., 2016) (Figure 2). Similar to human, NHP-PSC-derived HPs can be differentiated into T cells in coculture with OP9-DLL4 (D'Souza et al., 2016).

\section{Materials and Reagents}

A. Cell lines

1. hESC WA01 and WA09 (WiscBank, WiCell, Madison, WI)

2. Transgene-free iPSCs, DF-19-9-7T and 4-3-7T33 (WiscBank, WiCell, Madison, WI)

3. Mouse embryonic fibroblasts (MEFs, WiCell, Madison, WI)

4. Non-human primate PSCs (NHP-iPSCs), RhF5-iPS 19.1, Cy.F 3L iPS, and Cy0669\#1 iPS (D'Souza et al., 2016)

5. OP9 mouse bone marrow stromal cell line (Provided by Dr. Toru Nakano, Osaka University, Japan)

6. Lenti- $X^{\mathrm{TM}}$ 293T Cell Line (Clontech, catalog number: 632180)

B. Reagents

1. a-MEM basal medium, powder (Life Technologies, catalog number: 12000-022)

2. DMEM/nutrient mixture F-12, powder (Life Technologies, catalog number: 12400-024)

3. DMEM powder (Life Technologies, catalog number: 12100-046)

4. Iscove's Modified Dulbecco's Medium (IMDEM), powder (Life Technologies, catalog number: 122-00036)

5. Ham's F-12 Nutrient Mixture (F12), powder (Life Technologies, catalog number: 217-00075)

6. Chemically Defined Lipid Concentrate (CDLC) (Life Technologies, catalog number: 119-050-31)

7. GlutaMax (Life Technologies, catalog number: 35050-061)

8. Non-essential Amino Acids (NEAA) (Life Technologies, catalog number: 11140-076)

9. DPBS powdered, without calcium and magnesium (Life Technologies, catalog number: 21600044)

10. EDTA 0.5 M, pH 8.0 (Life Technologies, catalog number: 15575-038)

11. KnockOut Serun Replacement (KOSR) for hPSCs (Life Technologies, catalog number: 10828023)

12. TrypLe Select (Life Technologies, catalog number: 12563-029)

13. Collagenase type IV (Life Technologies, catalog number: 17104-019)

14. Puromycin (Life Technologies, catalog number: A1113803)

15. Primate ES cell medium (REPROCELL, catalog number: RCHEMD001) 
16. mTeSR1 defined feeder-free medium (StemCell Technologies, catalog number: 05850)

17. TeSR-E8 (E8) medium (Stem Cell Technologies, catalog number: 05990)

18. Vitronectin $\mathrm{XF}^{\mathrm{TM}}$ (VTN) (Stem Cell Technologies, catalog number: 07180)

19. Sodium Selenite (Millipore Sigma, catalog number: S5261)

20. Tenascin C (Millipore Sigma, catalog number: CC065)

21. Collagen IV (CollV) (Millipore Sigma, catalog number: C5533)

22. Acetic Acid (Millipore Sigma, catalog number: 537020)

23. Holo-transferrin (Millipore Sigma, catalog number: T0665)

24. Lithium Chloride (Millipore Sigma, catalog number: L9659)

25. 7-Aminoactinomycin D (7-AAD; Millipore Sigma, catalog number: A9400)

26. Human insulin (Millipore Sigma, catalog number: 19278)

27. Monothioglycerol (MTG) (Millipore Sigma, catalog number: S5261)

28. HEPES (Millipore Sigma, catalog number: $\mathrm{H} 4034$ )

29. Dextrose (Millipore Sigma, catalog number: G8270)

30. 2-mercaptoethanol (Millipore Sigma, catalog number: M7522)

31. Gelatin from porcine skin, Type A (Millipore Sigma, catalog number: G-1890)

32. Hexadimethrine bromide, Polybrene (Millipore Sigma, catalog number: H9268)

33. Fetal bovine serum, defined (HyClone, catalog number: $\mathrm{SH} 30070.03$ )

34. Trypsin 0.05\%/EDTA $0.5 \mathrm{mM}$ (HyClone, catalog number: SH30236.02)

35. Recombinant Human Flt3-Ligand (Peprotech, catalog number: 300-19)

36. Recombinant Human FGF basic (Peprotech, catalog number:100-18B)

37. Recombinant Human Stem Cell Factor (SCF) (Peprotech, catalog number: 300-07)

38. Recombinant Human Activin A (ActA) (Peprotech, catalog number: 120-14E)

39. Recombinant Human Interleukin 3 (IL-3) (Peprotech, catalog number: 200-03)

40. Recombinant Human Thrombopoietin (TPO) (Peprotech, catalog number: 300-18)

41. Recombinant Human Interleukin 6 (IL6) (Peprotech, catalog number: 200-06)

42. Recombinant Human Bone Morphogenic Protein 4 (BMP4) (Peprotech, catalog number: 12005ET)

43. Recombinant Human Vascular Endothelial Growth Factor (VEGF) (Peprotech, catalog number: 100-20)

44. Recombinant Human Interleukin 7 (IL7) (Peprotech, catalog number: 200-07)

45. GSK-3 $\beta$ inhibitor (CHIR99021) (Tocris, catalog number: 4423)

46. Rock inhibitor (Tocris, catalog number: 1254)

47. Human ES cell qualified Matrigel (Corning, catalog number: 354277 )

48. Calcium Chloride $\left(\mathrm{CaCl}_{2}\right)$ (Alfa Aesar, catalog number: 33296$)$

49. Potassium Chloride $(\mathrm{KCl})$ (Fisher Scientific ${ }^{\top \mathrm{M}}$, catalog number: BP366-1)

50. Sodium Chloride ( $\mathrm{NaCl}$ ) (Fisher Scientific ${ }^{\top M}$, catalog number: S642-212)

51. Sodium Bicarbonate (Fisher Scientific ${ }^{\mathrm{TM}}$, catalog number: S233-500)

52. Sodium azide, $\mathrm{NaN}_{3}$ (Fisher Scientific ${ }^{\top \mathrm{M}}$, catalog number: BP922-500) 
53. BSA fraction $V$ (Fisher Scientific ${ }^{\top M}$, catalog number: BP1600-100)

54. Sodium Phosphate Dibasic Anhydrous $\left(\mathrm{Na}_{2} \mathrm{HPO}_{4}\right)$ (Fisher Scientific ${ }^{\top \mathrm{M}}$, catalog number: BP3321)

55. Polyvinyl alcohol (PVA) (MP Biomedicals, catalog number: 151-941-83)

56. Doxycycline (DOX) (MP Biomedicals, catalog number: 198955)

57. Antibodies (Table 1)

Table 1. List of antibodies used

\begin{tabular}{llllll}
\hline Antigen & Fluorochrom & Clone & Company & Cat. No. & Species \\
\hline CD3 & FITC & SK7 & BD Biosciences & 349201 & Human \\
CD3 & APC & S4.1 & Caltag-Invirtogen & MHCD0305 & Human \\
CD3 & PE & SP34 & BD-Bioscience & 552127 & NHP \\
CD4 & APC & RPA-T4 & BD Biosciences & 555449 & Human \\
CD4 & PE & L200 & BD Biosciences & 550630 & NHP \\
CD5 & PE & UCHT2 & BD Biosciences & 555353 & Human \\
CD5 & APC & UCHT2 & Biolegend & 300611 & NHP \\
CD7 & FITC & M-T701 & BD Biosciences & 555360 & Human \\
CD7 & PE & M-T701 & BD Bioscience & 555361 & NHP \\
CD8 & PE & HIT8a & BD Biosciences & 555635 & Human \\
CD8 & APC & SK1 & Biolegend & 344721 & NHP \\
CD43 & FITC & 1 G10 & BD Biosciences & 555475 & Human \\
DLL4 & PE & 447506 & R\&D Systems & FAB1506P & Human \\
TCRa 3 & PE & T10B9.1A-BD & BD Biosciences & 555548 & Human \\
TCRa $\beta$ & APC & R73 & Biolegend & 201110 & NHP \\
CD34 & PE & 563 & BD Biosciences & 550761 & NHP \\
CD45 & FITC & MB4-6D6 & Miltenyl Biotech & $130-119-764$ & NHP \\
\hline
\end{tabular}

C. Materials

1. Cell strainer, $40 \mu \mathrm{m}$ (Fisher Scientific ${ }^{\mathrm{TM}}$, catalog number: 223663547)

2. Cell strainer, $70 \mu \mathrm{m}$ (Fisher Scientific ${ }^{\mathrm{TM}}$, catalog number: 22363548)

3. 9" Pasteur pipets, Flint glass (Fisher Scientific ${ }^{\top M}$, catalog number: 1367820D)

4. Serological Pipettes (10 ml, VWR International, catalog number: 89130-898)

5. Serological Pipettes ( $95 \mathrm{ml}, \mathrm{VWR}$ International, catalog number: 89130-896)

6. Nalgene Disposable bottle top filter, Polyethersulfone membrane with $0.2 \mu \mathrm{m}$ pore size (Fisher Scientific ${ }^{\top M}$, catalog number: $595-4520$ )

7. $0.5 \mathrm{ml}$ microcentrifuge tube, autoclavable (Fisher Scientific ${ }^{\mathrm{TM}}$, catalog number: 05-408-120)

8. Serological pipet, $1 \mathrm{ml}$ Nonpyrogenic (Fisher Scientific ${ }^{\text {TM }}$, catalog number: 13-678-11B)

9. Borosilicate glass pipets, $5 \mathrm{ml}$ (Fisher Scientific ${ }^{\mathrm{TM}}$, catalog number: $1367827 \mathrm{~F}$ )

10. $5 \mathrm{ml}$ Polystyrene round-bottom tube, $12 \times 75 \mathrm{~mm}$, non-sterile (BD Bioscience, catalog number: 352008)

11. MACS separation columns, LS (Miltenyi Biotec, catalog number: 130-042-401) 
12. MACS Multistand (Miltenyi Biotec, catalog number: 130-042-303)

13. Pre-separation filters with $30 \mu \mathrm{m}$ nylon mesh (Miltenyi Biotec, catalog number: 130-041-407)

14. Tissue culture dishes, polystyrene $100 \times 20 \mathrm{~mm}$ (Thermo Scientific, catalog number: 130182)

15. Tissue culture 6-well plate, Polystyrene flat bottom (Thermo Scientific, catalog number: 130184)

16. $15 \mathrm{ml}$ Polypropylene Conical tubes (Thermo Scientific Nunc, catalog number: 339650)

17. $50 \mathrm{ml}$ Polypropylene Conical tubes (Thermo Scientific, catalog number: 339652)

18. Steriflip Filter Units, $50 \mathrm{ml}$ Vacuum filtration system with $0.22 \mu \mathrm{m}$ pore size membrane (Millipore Sigma, catalog number: SCGP00525)

19. Serological pipet, $5 \mathrm{ml}$ Nonpyrogenic (VWR, catalog number: 89130-896)

20. Serological pipet, $10 \mathrm{ml}$ Nonpyrogenic (VWR, catalog number: 89130-898)

21. Sterling Nitrile-xtra powder-free exam gloves (Kimberly-Clark, catalog number: 53139)

D. Medium and solutions

1. Human PSC growth Medium (see Recipes)

2. MEF growth medium (see Recipes)

3. NHP-iPSC Primate PSCs Medium (see Recipes)

4. Mouse OP9/OP9-DLL4 bone marrow stromal cell culture medium (see Recipes)

5. Human hematopoietic differentiation (OP9 coculture system) medium (see Recipes)

6. NHP differentiation medium (see Recipes)

7. IF4S Stock Medium (see Recipes)

8. 5x PVA Stock Solution (see Recipes)

9. IF9S Medium (see Recipes)

10. T lymphoid differentiation medium (see Recipes)

11. HBS saline solution (2x) (see Recipes)

12. $\mathrm{CaCl}_{2}$ solution (2 M) (see Recipes)

13. Gelatin solution $(0.1 \%$ (wt/vol) (see Recipes)

14. Magnetic cells sorting (MACS) buffer (see Recipes)

15. Flow cytometry buffer (see Recipes)

16. Reconstitution of cytokines (see Recipes)

17. Collagenase solution $(1 \mathrm{mg} / \mathrm{ml}$ ) (see Recipes)

18. Doxycycline (1 mg/ml) (see Recipes)

\section{Equipments}

1. MACSQuant analyzer (Miltenyl Biotech, catalog number: 130-096-343)

2. Cellometer ${ }^{R}$ Auto 2000 cell Viability Counter (Nexcelom Bioscience, model: 2000)

3. Hemocytometer, Reichert Bright-Line counting chamber (Fisher Scientific ${ }^{\mathrm{TM}}$, catalog number: 02-671-5)

4. MACSmix Tube Rotator (Miltenyi Biotec, catalog number: 130-090-753) 
5. Water bath (Fisher Scientific, catalog number: 16-462-10)

6. Thermo IEC Centra CL2 Centrifuge (Thermo Scientific, model: 4992)

7. Microcentrifuge (Eppendorf, model: 5418)

8. Centricon Plus-70 Centrifugal Filter (Millipore Sigma, catalog number: UFC701008)

9. Sterile biosafety cabinet (The Baker Company, model: SG603)

10. $37{ }^{\circ} \mathrm{C} / 5 \% \mathrm{CO}_{2}$ incubator (Thermo Scientific, model: MCO-19A1)

11. Hypoxia incubator (Thermo Scientific, model: MCO-19M-PA)

12. Inverted microscope with objective lenses $4 x, 10 x$ and 20x (Olympus, model: IX71)

13. Object marker, Cell dotter for inverted microscope (Nikon, catalog number: MBW10020)

14. Balance (Denver Instrument, model: APX60)

15. Milli-Q water purification system (Millipore, Billerica, MA, USA)

16. Pipet-Aid, Filler/Dispensers (Drummond, model: 4-000-300)

17. Liquid waste disposal system for aspiration

18. Beckman Optima XL-A analytical ultracentrifuge (Beckman Coulter, catalog number: 369005)

19. Bright-Field microscope (Olympus, model: CKX31SF)

\section{Software}

1. FlowJo ${ }^{T M}$ software (v10.6.1) (BD Bioscience, https://www.flowjo.com/)

2. GraphPad Prism 7 (GraphPad, www.graphpad.com)

\section{Procedure}

A. Coating of matrix

1. Prepare gelatin-coated $10 \mathrm{~cm}$ culture dish $(10 \mathrm{ml} / \mathrm{dish})$ or 6 -well plate $(2 \mathrm{ml} /$ well $)$ by adding sterile gelatin solution and allowing the gelatin solution to cover the entire plastic surface. Incubate the plasticware at least $3 \mathrm{~h}$ at $37^{\circ} \mathrm{C}$ in an incubator. Gelatin coated dishes/ plates are used for culture for OP9/OP9-DLL4/MEFs.

2. Prepare VTN or Matrigel-coated 6-well plate by adding $2 \mathrm{ml}$ of the coating solution to each well of the 6-well plate and incubate at $4{ }^{\circ} \mathrm{C}$ overnight. The coated plate can be stored in $4{ }^{\circ} \mathrm{C}$ for up to 1 month. VTN/Matrigel coated plates are used for culture of PSCs under feeder free conditions.

3. Prepare a TenC or CollV coating solution by adding $2 \mathrm{ml}$ of the coating solution to each well of a 6-well plate and incubate at $4{ }^{\circ} \mathrm{C}$ overnight. The coated plate can be stored in $4{ }^{\circ} \mathrm{C}$ for up to 1 month. TenC/CollV coated plates are used for hematopoietic differentiation of PSCs under feeder free conditions.

B. Culture of hPSCs/NHP-PSCs on feeder cells (MEFs)

1. Resuspend inactivated MEFs (provided by WiCell) at $2 \times 10^{5} \mathrm{cells} / \mathrm{ml}$ in pre-warmed $\left(37^{\circ} \mathrm{C}\right.$ ) 
MEF growth medium.

2. Add $2 \mathrm{ml} /$ well of prewarmed MEF growth medium and then dispense MEF suspension on a gelatin-coated 6-well plate $(1 \mathrm{ml} / \mathrm{well})$ and distribute MEFs evenly with a back and forth movement of the plate.

3. Incubate MEF plates in a $5 \% \mathrm{CO}_{2}$ incubator at $37^{\circ} \mathrm{C}$ for at least $24 \mathrm{~h}$ before adding $\mathrm{hPSC}$ or NHP-PSCs.

4. Aspirate growth medium from 1 well of the 6-well plate of hPSCs or NHP-PSCs.

5. Add $2 \mathrm{ml} /$ well of collagenase IV solution $(1 \mathrm{mg} / \mathrm{ml})$ and incubate at $37^{\circ} \mathrm{C}$ in $\mathrm{CO}_{2}$ incubator until the edges of the hPSCs or NHP-PSCs colonies begin to detach (approximately 7-10 min for hPSCs and 4-5 min for NHP-PSCs).

6. Aspirate collagenase, add $2 \mathrm{ml}$ of growth medium and disperse the colonies into small cell aggregates by pipetting gently for couple of times until all cells are in suspension.

7. Transfer the cells to a $15 \mathrm{ml}$ conical tube and centrifuge at $300 \times \mathrm{g}$ at room temperature for 3 min.

8. Aspirate the medium gently, resuspend the cells in $4-6 \mathrm{ml}$ growth medium and break hPSC or NHP-PSCs colonies into small aggregates with a glass pipette.

9. Plate the cell suspension onto a confluent MEF grown 6-well plate from Step B3 (Splitting ratio for hPSCs is $1: 6$ and for NHP-PSCs is 1:4).

C. Culture of hPSCs or iETS1 hPSCs in feeder-free conditions

1. Aspirate VTN or Matrigel coating solution from each well and add $1 \mathrm{ml}$ of TeSR-E8 (E8) in case of a VTN plate or mTeSR1 for a Matrigel plate.

2. To passage the PSCs, aspirate spent media from one well of PSCs culture plate and add EDTAPBS solution (2 $\mathrm{ml} /$ well).

3. Incubate the plate for $3-4$ min at $37{ }^{\circ} \mathrm{C}$ with $5 \% \mathrm{CO}_{2}$.

4. Carefully aspirate EDTA-PBS solution and add $1 \mathrm{ml}$ of E8 or mTeSR1.

5. Gently pipette to dislodge the cells and collect into a $15 \mathrm{ml}$ conical tube.

6. Adjust the volume to $6 \mathrm{ml}$ with E8 or mTeSR1.

7. Mix well and add cell suspension ( $1 \mathrm{ml} /$ well of 6 -well plate) to VTN or Matrigel-coated plate.

8. Thereafter change spent media to fresh E8 or mTeSR1 media daily.

D. Human DLL4 lentivirus production

1. Subculture $293 \mathrm{~T}$ cells the day before transfection to $60-70 \%$ confluency in $9 \mathrm{ml}$ of DMEM medium with $10 \%$ FBS per $100 \mathrm{~mm}$ dishes.

2. On day 0, perform Calcium phosphate $\left(\mathrm{CaPO}_{4}\right)$ transfection of $293 \mathrm{~T}$ cells in the morning. For $\mathrm{CaPO}_{4}$ transfection, for each dish, make a mixture containing $10 \mu \mathrm{g}$ of expression lentiviral vector containing hDLL4 (pSIN4-EF1a-hDLL4-IRES-Puro), $10 \mu \mathrm{g}$ of packaging vector, $7.5 \mu \mathrm{g}$ of envelope vector, $62 \mu \mathrm{l}$ of $2 \mathrm{M} \mathrm{CaCl}_{2}$ and make up the volume to $500 \mu \mathrm{l}$ with deionized autoclaved water. 
3. Add $500 \mu \mathrm{l}$ of $2 x$ HBS dropwise into this mixture while bubbling using another $1 \mathrm{ml}$ pipette.

4. Bubble the mixture for an additional 5-10 s. Incubate the mixture for $15-20 \mathrm{~min}$ at room temperature.

5. Add the mixture to the 293T cells dropwise while continuously swirling the dish.

6. Place the dish into a $5 \% \mathrm{CO}_{2}$ incubator at $37^{\circ} \mathrm{C}$ for $6-8 \mathrm{~h}$.

7. Aspirate the medium after $8 \mathrm{~h}$ of incubation.

8. Add $8 \mathrm{ml}$ of fresh medium to the dishes and continue the culture for another 2 days.

9. On day 3 , harvest the medium containing virus into $50 \mathrm{ml}$ tubes.

10. Centrifuge the supernatant at $700 \times \mathrm{g}$ for $10 \mathrm{~min}$ at room temperature.

11. The supernatant containing the virus can be stored at $-70{ }^{\circ} \mathrm{C}$ or concentrated using ethylene oxide-sterilized Centricon Plus-70 or Amicon Ultra-15 Centrifugal Filter Units.

12. To calculate the amount of Infectious Units (IFU) per $\mathrm{ml}$ of viral concentrate, transduce HeLa cells with the virus and select with puromycin $(1 \mu \mathrm{g} / \mathrm{ml})$.

E. Generation of human DLL4 expressing mouse OP9 stromal cells

1. Aspirate the gelatin solution from the dish. Do not allow dishes to dry.

2. Thaw OP9 cells quickly in a $37^{\circ} \mathrm{C}$ water bath.

3. Pipette the cell suspension slowly and transfer the contents to the $15-\mathrm{ml}$ tube containing $5 \mathrm{ml}$ of medium.

4. Centrifuge the cells at $300 \times \mathrm{g}$ for $5 \mathrm{~min}$ at $4{ }^{\circ} \mathrm{C}$ and resuspend the cells in $10 \mathrm{ml}$ of OPg medium.

5. Transfer the resuspended cells into a $10-\mathrm{cm}$ dish, and place the dish in a $37^{\circ} \mathrm{C}$ incubator with $5 \% \mathrm{CO}_{2}$.

6. For viral transduction, add polybrene $(6 \mu \mathrm{g} / \mathrm{ml})$ to the culture medium.

7. Add hDLL4 lentivirus to the cells at an $\mathrm{MOI}$ of 10 and incubate the culture dish at $37^{\circ} \mathrm{C}$ with $5 \%$ $\mathrm{CO}_{2}$ for $24 \mathrm{~h}$.

8. Repeat viral transduction one more time as described in E7-E8.

9. Select the transduced OP9-DLL4 cells by adding $20 \mathrm{ng} / \mathrm{ml}$ of puromycin into the culture medium.

10. To confirm the transduction of hDLL4 into OP9, resuspend the cells into $100 \mu \mathrm{l}$ FACS buffer and stain with human DLL4 antibody for 20 min at room temperature (Table 1).

11. Wash the stained cells with FACS buffer and perform flow cytometry.

F. Maintenance of OP9/OP9-DLL4 cells

1. To passage the cells, aspirate OP9 growth medium and wash OP9/OP9-DLL4 cells twice with $10 \mathrm{ml}$ of PBS.

2. Add $5 \mathrm{ml}$ of trypsin/EDTA [0.05\% (wt/vol)] solution and incubate for $10 \mathrm{~min}$ at $37^{\circ} \mathrm{C}$ in a $5 \% \mathrm{CO}_{2}$ incubator.

3. Add $5 \mathrm{ml}$ of OP9 growth medium and collect cells by pipetting up and down until single cell suspension is formed.

4. Transfer cell suspension into a $15-\mathrm{ml}$ conical tube and centrifuge for $5 \mathrm{~min}$ at $300 \times \mathrm{g}$ at room 
temperature.

5. Aspirate supernatant and resuspend the cells in $1 \mathrm{ml}$ of OP9 growth medium.

6. Add $100 \mu \mathrm{l}$ of the cell suspension to $10 \mathrm{ml}$ of OP9 growth medium and plate cells onto $10-\mathrm{cm}$ gelatin-coated culture dishes.

7. When cultures are confluent, split one dish for maintenance.

8. 8-9 days old OP9 dishes should be used for hematopoietic differentiation for human ESCs and 5-6 days old OP9 dishes should be used for NHP-iPSCs hematopoietic differentiation.

9. 3-4 days old OP9-DLL4 should be used for subsequent protocol, i.e., T lymphoid differentiation.

G. Hematopoietic differentiation

\section{Human PSCs on OPg}

1. From 1 well of a 6-well hPSC plate, aspirate hESC growth medium. Add $2 \mathrm{ml}$ of collagenase IV solution $(1 \mathrm{mg} / \mathrm{ml})$ and incubate cells for $10 \mathrm{~min}$ at $37^{\circ} \mathrm{C}$ (Figure 1 ).

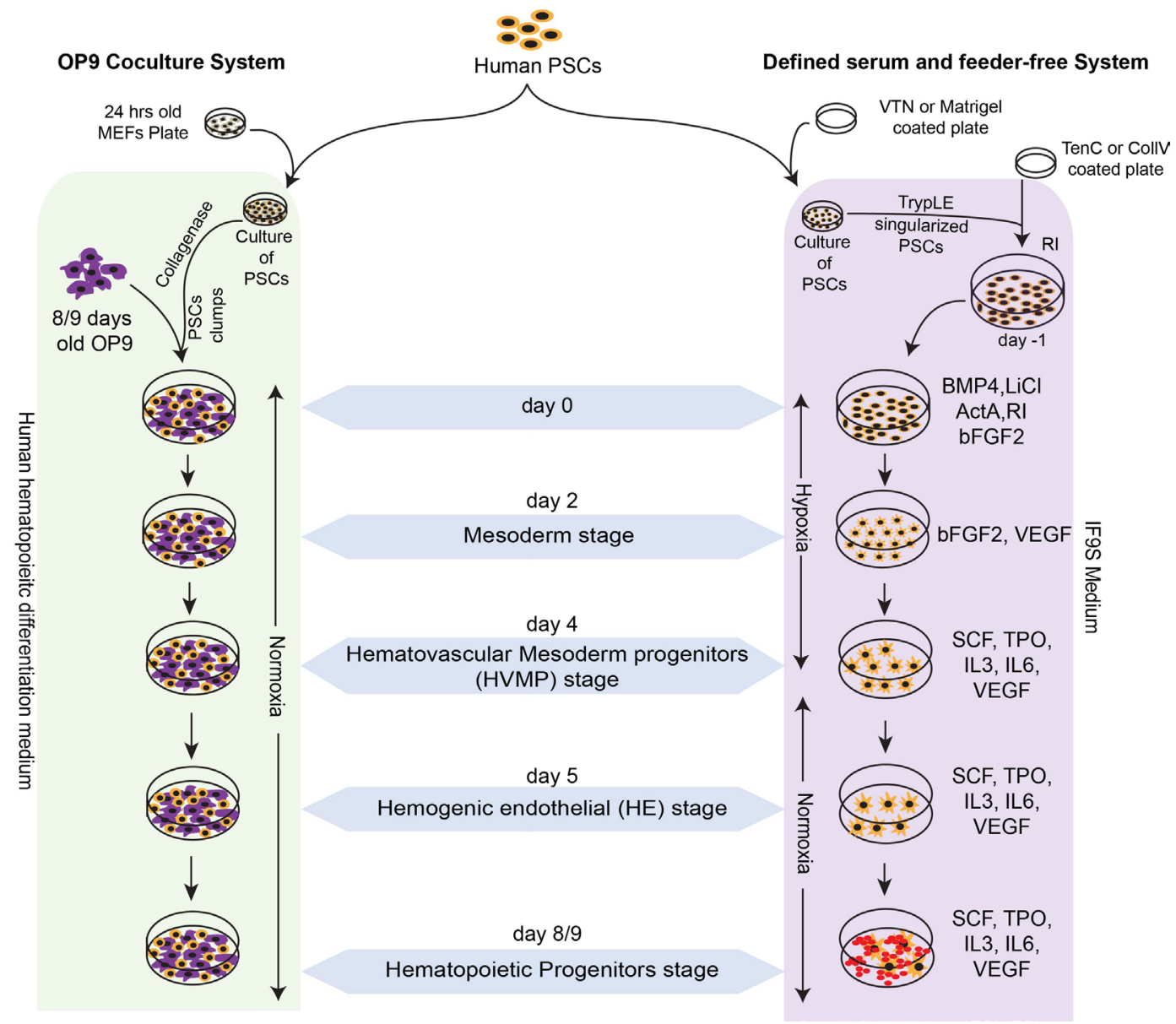

Figure 1. Schematic diagram shows the culture and hematopoietic differentiation of human pluripotent stem cells in serum free chemically defined feeder-free condition and on OP9 coculture system. Use various MACS enriched progenitor from OP9 coculture system and floating cells from feeder free system for T lymphoid differentiation. 
2. Aspirate collagenase IV solution and add $2 \mathrm{ml}$ per well of growth medium directly to the well and break up colonies into small cell aggregates by gently pipetting. Transfer cells into a $15-\mathrm{ml}$ conical tube.

3. Centrifuge cells at $300 \times g$ for $5 \mathrm{~min}$ at room temperature. Aspirate the medium gently without disturbing the pellet.

4. Resuspend the pelleted cells into $10 \mathrm{ml}$ of differentiating medium.

5. For coculture, aspirate the OP9 growth medium from overgrown OP9 dishes.

6. Add $10 \mathrm{ml}$ of cell suspension from Step 4 on OP9 dishes.

7. Evenly spread the cells on the OP9 Monolayer by moving the dish in a back/forth and right/left movement twice and keep at $37^{\circ} \mathrm{C}$ in a $5 \% \mathrm{CO}_{2}$ incubator.

8. On day 1 aspirate all of the medium and replace it with $10 \mathrm{ml}$ of differentiation medium.

9. On day 4 and day 6 , aspirate $5 \mathrm{ml}$ of spent media and add $5 \mathrm{ml}$ of fresh differentiating medium.

10. On day 9 , aspirate all of the medium and add $5 \mathrm{ml}$ of collagenase solution to each dish of coculture and incubate for $20 \mathrm{~min}$ at $37^{\circ} \mathrm{C}$ in a $\mathrm{CO}_{2}$ incubator.

11. Remove the collagenase solution and keep it on ice in a $50-\mathrm{ml}$ conical tube.

12. Add $5 \mathrm{ml}$ of Trypsin/EDTA solution [0.05\% (wt/vol)] to the dish and incubate for $10 \mathrm{~min}$ at $37^{\circ} \mathrm{C}$ in a $5 \% \mathrm{CO}_{2}$ incubator.

13. Add $5 \mathrm{ml}$ per dish of MACS buffer, suspend cocultured cells by pipetting and transfer to the collection tube from Step 11.

14. Centrifuge the cell suspension at $300 \times g$ for $5 \mathrm{~min}$ at room temperature.

15. Resuspend the pelleted cells with $5 \mathrm{ml}$ of MACS buffer and centrifuge at $300 \times g$ for $5 \mathrm{~min}$ at room temperature.

16. Resuspend cells in 0.5-1 ml of MACS buffer.

17. Stain the cells with anti-human CD43-FITC antibody.

18. Place the tube on the MACS mixer and incubate at $4{ }^{\circ} \mathrm{C}$ for $20-25 \mathrm{~min}$.

19. Wash cells with ice-cold MACS buffer as described in Step 15.

20. Resuspend in $80 \mu$ of MACS buffer and add anti- FITC magnetic beads.

21. Repeat Step 18.

22. Wash cells with ice-cold MACS buffer, as described in Step 15, and resuspend in $2 \mathrm{ml}$ of MACS buffer.

23. Filter cells through a $30 \mu \mathrm{m}$ pre-separation filter.

24. Assemble the MACS-LS separation unit according to the manufacturer's instructions.

25 . Rinse the column with $2 \mathrm{ml}$ of MACS buffer.

26. To purify $\mathrm{CD}_{4} 3^{+}$multipotent progenitors, apply the cell suspension from Step 22 into the LS column and allow cells to pass completely through the column into the collection tube.

27. Wash the column with $2 \mathrm{ml}$ of MACS buffer and collect it in the same collection tube.

28. Discard the cell suspension in the collection tube.

29. Remove the column from the magnet and place it on an empty $15-\mathrm{ml}$ tube.

30. Wash out $\mathrm{CD} 43^{+}$cells with $5 \mathrm{ml}$ of MACS buffer using the plunger supplied with the column. 
31. Centrifuge cells at $300 \times g$ for 5 min at $4{ }^{\circ} \mathrm{C}$.

32. Resuspend cells in $0.2 \mathrm{ml}$ of MACS buffer.

33. The MACS enriched $C D 43^{+}$multipotent hematopoietic progenitor cells are ready to be used for T lymphoid differentiation.

\section{Human PSCs or iETS1-PSCs in a defined serum and feeder-free system}

1. Prepare a single-cell suspension of human ESCs by using TrypLE select. Add $1 \mathrm{ml} /$ well of TrypLE solution to $80 \%$ confluent ESC plate and incubate for $4 \min 37^{\circ} \mathrm{C}$ with $5 \% \mathrm{CO}_{2}$ (Figure 1).

2. Harvest the cells in $1 \mathrm{ml}$ TrypLE solution and collect it into a $15 \mathrm{ml}$ conical tube with $9 \mathrm{ml}$ of E8 medium.

3. Centrifuge $300 \times g$ for $5 \mathrm{~min}$ at room temperature.

4. Resuspend the pelleted cells in $6 \mathrm{ml}$ of fresh E8 media and count the cells.

5. Aspirate TenC or CollV coating solution from each well of the coated plate.

6. Add $1 \mathrm{ml}$ of E8 media with $10 \mu \mathrm{M}$ of rock inhibitor to each well of the coated plate.

7. Transfer the optimized number of cells from Step F4 to a new $15 \mathrm{ml}$ conical tube and adjust the volume to $6 \mathrm{ml}$.

8. Add $1 \mathrm{ml}$ of E8 containing ESCs into each well of Ten-C coated plates.

9. Incubate overnight at $37^{\circ} \mathrm{C}$ in $5 \% \mathrm{CO}_{2}$.

10. On day 0 , aspirate E8 media and add $2 \mathrm{ml} /$ well of differentiating medium (IF9S) containing Activin A (18 ng/ml), BMP4 (50 ng/ml), bFGF2 (50 ng/ml), LiCl $(2 \mathrm{mM})$ and Rock inhibitor (1 $\mu \mathrm{M})$.

11. Place the cells in a hypoxia $\left(5 \% \mathrm{O}_{2}\right)$ incubator. During the next two days, do not remove the plate from the incubator.

12. On day 2, aspirate the spent differentiating medium and add $2 \mathrm{ml} /$ well of fresh differentiating media with VEGF $(50 \mathrm{ng} / \mathrm{ml})$ and bFGF2 $(50 \mathrm{ng} / \mathrm{ml})$. Treat iETS1-PSCs differentiating plate with Doxycycline $(2 \mu \mathrm{g} / \mathrm{ml})$.

13. Place the cells back in the hypoxic incubator, i.e., $37^{\circ} \mathrm{C}$ with $5 \% \mathrm{CO}_{2}$.

14. On day 4 , aspirate the spent differentiating medium and add $2 \mathrm{ml} /$ well of fresh differentiating medium with SCF (50 ng/ml), VEGF (50 ng/ml), TPO (50 ng/ml), IL6 $(50 \mathrm{ng} / \mathrm{ml})$, IL3 $(10 \mathrm{ng} / \mathrm{ml})$ and FLT3-L (10 ng/ml). Treat iETS1-PSCs differentiating plate with Doxycycline $(2 \mu \mathrm{g} / \mathrm{ml})$.

15. Place the cells in the normoxic incubator.

16. On day 6 , add $1 \mathrm{ml} /$ well of fresh differentiating medium with cytokines from Step 14.

17. On days 8-9, collect the floating multipotent HPs by passing through a $70 \mu \mathrm{m}$ filter and use them for further Lymphoid differentiation.

\section{Nonhuman Primate PSCs on OP9}

1. From 1 well of a 6-well NHP-PSCs plate, aspirate NHP-PSC growth medium. Add $2 \mathrm{ml}$ of collagenase IV solution $(1 \mathrm{mg} / \mathrm{ml})$ and incubate the cells for 5 min at $37^{\circ} \mathrm{C}$. 
2. Aspirate collagenase IV solution and add $2 \mathrm{ml}$ per well of growth medium directly to the well and break up colonies into small cell aggregates by gently pipetting. Transfer cells into a $15-\mathrm{ml}$ conical tube.

3. Centrifuge cells at $300 \times \mathrm{g}$ for $5 \mathrm{~min}$ at room temperature. Aspirate the medium gently without disturbing the pellet.

4. Resuspend the pelleted cells into $10 \mathrm{ml}$ of Primate differentiating medium.

5. Remove 6-7 days old OP9 dishes prepared for coculture from the incubator and aspirate OP9 growth medium (Figure 2).

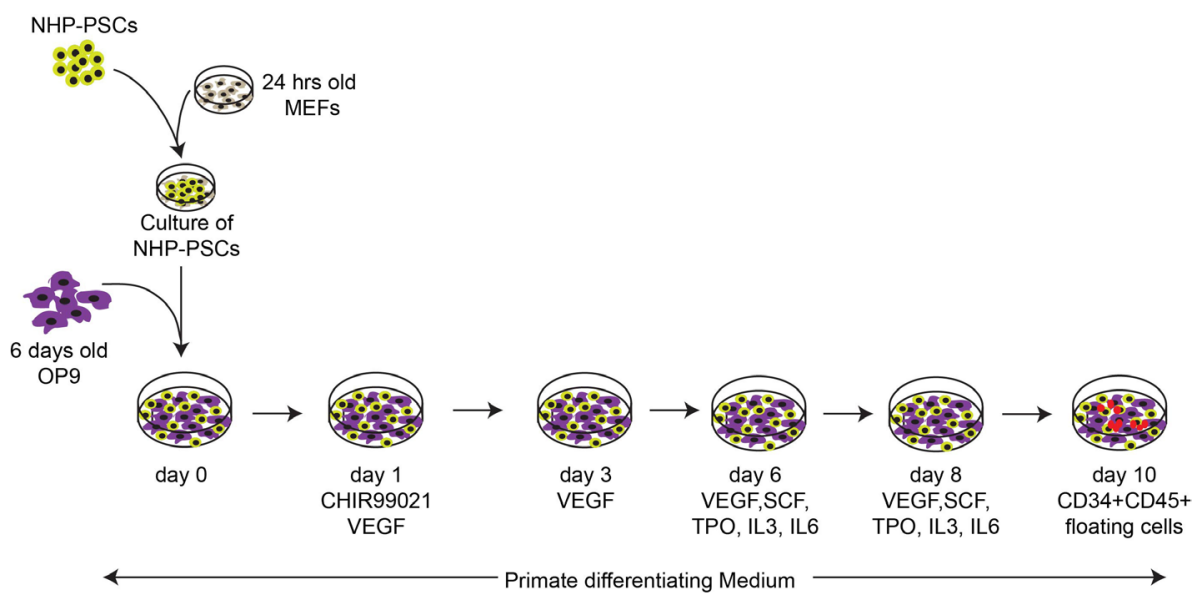

Figure 2. Schematic representation of the established differentiation protocol for induction of mesoderm and blood formation for the NHP iPSCs. Hematopoietic differentiation of NHP-PSCs was induced in coculture with OP9 in the presence of GSK3b inhibitor. Use floating $\mathrm{CD} 34^{+} \mathrm{CD} 45^{+}$cells for $\mathrm{T}$ lymphoid differentiation.

6. Add the cells from Step 4 to the OP9 dish and move the dish back and forth to unformily spread the cells on the OP9 monolayer (day 0 ).

7. On day 1 of coculture, aspirate the medium and add $10 \mathrm{ml}$ of primate differentiation medium with $4 \mu \mathrm{M}$ of CHIR99021 and $50 \mathrm{ng} / \mathrm{ml}$ of VEGF.

8. On day 3 , aspirate the medium and add fresh $10 \mathrm{ml}$ of fresh primate differentiation media with $50 \mathrm{ng} / \mathrm{ml}$ of VEGF.

9. On day 6 , hematopoietic cytokine cocktail containing $50 \mathrm{ng} / \mathrm{ml}$ of VEGF, $50 \mathrm{ng} / \mathrm{ml}$ of SCF, $20 \mathrm{ng} / \mathrm{ml}$ of TPO, $20 \mathrm{ng} / \mathrm{ml}$ of IL-3 and $20 \mathrm{ng} / \mathrm{ml}$ of IL- 6 in primate differentiating medium is added to the coculture.

10. On day 8 repeat Step 9 .

11. On day 10 of coculture, collect the floating multipotent HPs are collected by passing through a $70 \mu \mathrm{m}$ filter and use them for further Lymphoid differentiation.

H. Lymphoid differentiation on OP9-DLL4 coculture system

1. Prepare the OP9-DLL4 containing 6-well plates by seeding $0.5 \times 10^{5}$ OP9-DLL4 cells per well 
(Figure 3).

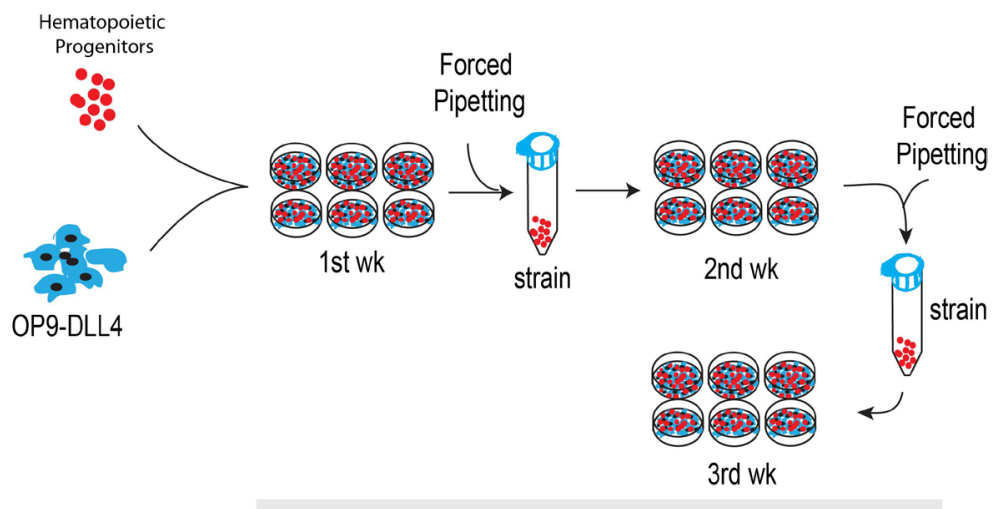

T Lymphoid differentiation media +SCF+FLT3L+IL7

Figure 3. Schematic diagram shows the T lymphoid differentiation of HPs from different sources. Collect and count the HPs from OP9/hPSC or OP9/NHP-PSCs or feeder-free system and culture on OP9-DLL4 to induce T cell differentiation.

2. Culture the cells at $37^{\circ} \mathrm{C}$ with $5 \% \mathrm{CO}_{2}$ for $3-4$ days or until a monolayer of cells is formed.

3. Once the OP9-DLL4 plate is ready for coculture, seed the HPs cells from different sources $(1 \mathrm{x}$ $10^{5}-3 \times 10^{5}$ cells/well of 6 -well plate) on the OP9-DLL4 with T cell media (OP9 medium containing $20 \%$ FBS with FLT3-L ( $5 \mathrm{ng} / \mathrm{ml})$, IL-7 $(5 \mathrm{ng} / \mathrm{ml})$ and SCF $(10 \mathrm{ng} / \mathrm{ml}))$.

4. Culture the plates for $3-4$ weeks at $37{ }^{\circ} \mathrm{C}$ with $5 \% \mathrm{CO}_{2}$ in an incubator and passage weekly.

5. On day 3 , add $1 \mathrm{ml}$ of fresh $\mathrm{T}$ cell differentiation media and prepare a new OP9-DLL4 plate for cell transfer on days 6-7.

6. On days $6-7$, dislodge the progenitor cells by vigorously pipetting and collect the cells into a $15 \mathrm{ml}$ conical tube (Figure 3).

7. Filter the cells using a $40 \mu \mathrm{m}$ strainer.

8. Centrifuge the cells at $300 \times g$ for $5 \mathrm{~min}$ at room temperature.

9. Aspirate the supernatant and resuspend the cells in $2 \mathrm{ml}$ of $\mathrm{T}$ cell medium and transfer onto a fresh OP9-DLL4 monolayer (Figure 3).

10. On day 10 , add $1 \mathrm{ml}$ of fresh T cell differentiation media and prepare a new OP9-DLL4 plate for cell transfer on days 13-14.

11. On days $13-14$, repeat Steps $\mathrm{H} 6-\mathrm{H} 10$.

12. On day 18 , add $1 \mathrm{ml}$ of fresh $\mathrm{T}$ cell differentiation media and prepare a new OP9-DLL4 plate for cell transfer on days 20-21.

13. On days 20-21, repeat Steps $\mathrm{H} 6-\mathrm{H} 10$.

14. On day 24 , add $1 \mathrm{ml}$ of fresh $\mathrm{T}$ cell differentiation media and prepare a new OP9-DLL4 plate for cell transfer.

15. On day 27 , harvest the cells by vigorously pipetting and straining into a $15 \mathrm{ml}$ conical tube.

16. Centrifuge the cells at $300 \times g$ for $5 \mathrm{~min}$ at room temperature. Aspirate the supernatant and resuspend the cells in $1 \mathrm{ml}$ of flow cytometry buffer. 
17. Evaluate the $T$ cell differentiation by flow cytometry analysis of $T$ cell markers (CD5, CD7, CD8, CD4, CD3, and TCRaß) (Table 1) using MACSQuant Analyser 10 (Figure 4).

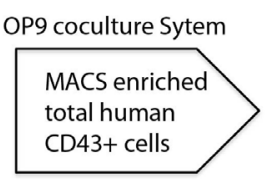

B

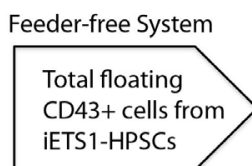

C

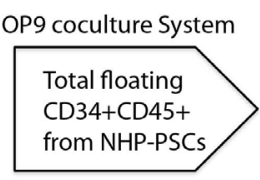

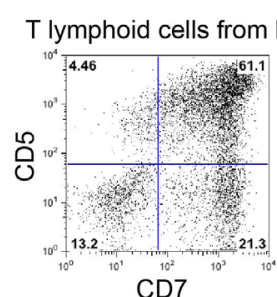
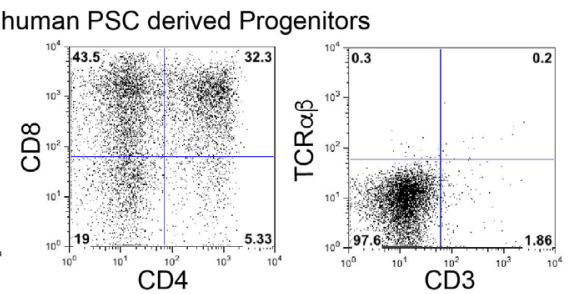

T lymphoid cells from ETS1-PSC derived Progenitors
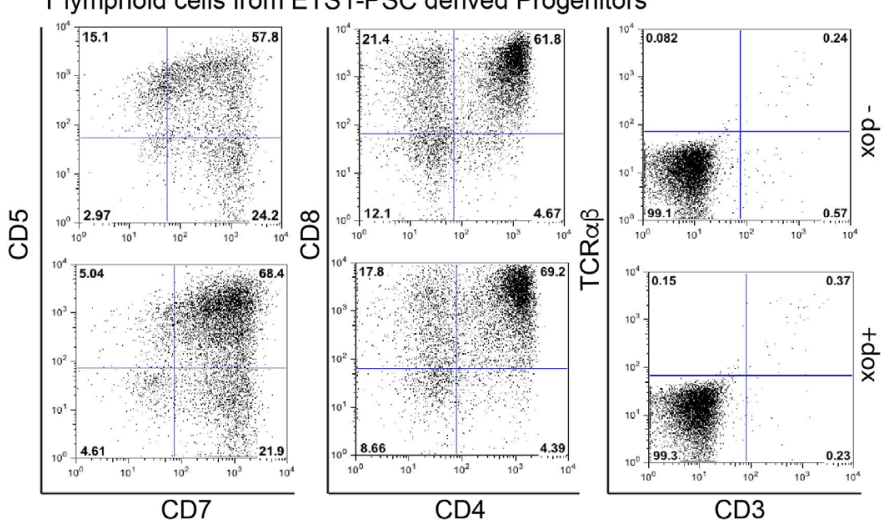

T lymphoid cells from NHP-IPSC derived Progenitors
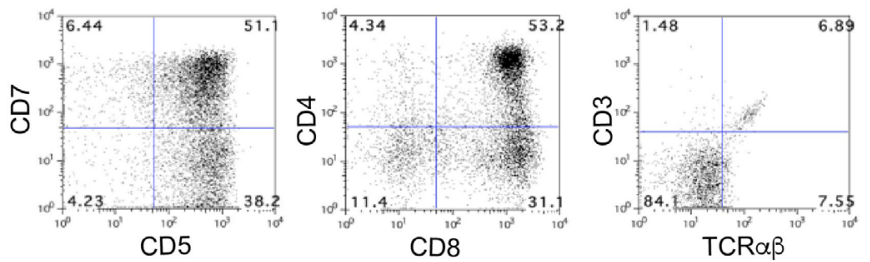

Figure 4. T cell potential of HPs. A. Flow cytometric profile of T cells generated after 3 weeks of culture of total $\mathrm{CD}_{4} 3^{+}$on OP9-DLL4 from the indicated human PSCs differentiated on OP9 for 8/9 days. B. Flow cytometric profile of T cells generated from iETS1-PSCs. iETS1-PSCs were differentiated with doxycycline or without doxycycline in chemically defined feeder free system for 9 days and floating cells were collected on day 9. C. Flow cytometric profile of T cells generated after 3 weeks of culture of $\mathrm{CD} 34^{+} \mathrm{CD} 45^{+}$on OP9-DLL4 from NHP-PSCs.

\section{Data analysis}

1. The flow cytometry data was analyzed using FlowJo software (v10.6.1). Live cells were gated based on the 7AAD population to remove the dead cells.

2. The significance of differences between the mean values was determined by one-way ANOVA followed by Tukey post hoc test as appropriate using GraphPad Prism software (GraphPad, San Diego, CA). 


\section{$\underline{\text { Notes }}$}

1. hPSCs cultured on MEFs needs to be split once every 6-7 days whereas NHP-PSCs cultures need to be split once every 4 days.

2. Growth medium used to culture PSCs depends on the type of feeder/ matrix used for culture. For hPSCs grown on vitronectin use E8, while for those grown on Matrigel use mTeSR1. For hPSCs gown on MEFs use PSC growth medium, while for NHP-PSCs grown on MEFs use NHP-PSC medium.

3. After collagenase treatment, hPSCs/NHP-PSCs colonies are loosely attached and can be collected by gentle pipetting. Do not use excessive mechanical force or scraping, which can provoke spontaneous differentiation.

4. If spontaneous differentiation of hPSCs/ NHP iPSCs occurs, differentiated colonies should be eliminated during the maintenance; observe PSCs every day before changing the medium. Mark differentiated colonies with an objective marker under the inverted microscope and aspirate marked areas using a glass Pasteur pipette while feeding PSCs with fresh medium.

5. Matrigel is temperature sensitive and should be kept on ice during handling. It is recommended to avoid freeze/thaw cycles by preparing $200 \mu \mathrm{l}$ aliquots for four 6-well plates and storing at $-20{ }^{\circ} \mathrm{C}$. Specific aliquot volumes vary by lot. Quickly dissolve each aliquot in $48 \mathrm{ml}$ cold PBS and subsequently add $2 \mathrm{ml}$ to each well of a 6-well plate. Incubate at least $1 \mathrm{~h}$ at room temperature or store overnight at $4{ }^{\circ} \mathrm{C}$ until ready to use. Matrigel-coated plates can be kept for several weeks at $4{ }^{\circ} \mathrm{C}$.

6. Vitronectin is not temperature sensitive and can be thawed at room temperature. Dilute Vitronectin in $1 \times$ PBS to reach a final concentration of $10 \mu \mathrm{g} / \mathrm{ml}(2 \mathrm{ml}$ Vitronectin $/ 50 \mathrm{ml} \mathrm{1x} \mathrm{PBS})$ and gently mix by pipetting. Coat $1 \mathrm{ml} /$ well of 6 -well tissue-culture plate with diluted Vitronectin. Incubate for at least $1 \mathrm{~h}$ at room temperature before use. If it is not used immediately, the coated culture plate must be sealed and can be stored up to 1 week at $4{ }^{\circ} \mathrm{C}$. Stored, coated culture plates must be brought to room temperature $30 \mathrm{~min}$ before cells are passaged.

7. hPSCs can be maintained under feeder-free conditions. For the OP9 coculture system, we always prefer to use hPSCs or NHP-iPSCs maintained on MEFs. hPSCs maintained under feeder-free conditions are used for hematopoietic differentiation under chemically defined feeder-free conditions. We observe substantial differences in the efficiency of hematopoietic differentiation of hPSCs/NHP iPSCs maintained on MEFs or in feeder-free cultures in the OP9 coculture system.

8. We found that engineered iETS1 hPSCs retain undifferentiated morphology and efficient hematopoietic differentiation potential when maintained on Matrigel-coated plates. In contrast, cultures on vitronectin-coated plates, iETS1 cells do not exhibit uniform morphology and fail to differentiate efficiently.

9. It is essential to culture OP9/OP9-DLL4 on gelatin-coated plates to prevent spontaneous adipogenesis. 
10. Human hematopoietic differentiation on OP9 coculture system prefers over-confluent OP9 (8-9 days) whereas NHP iPSCs hematopoietic differentiation on OP9 coculture system prefers 6-7 day old OP9 cultures.

11. Human hematopoietic differentiation in chemically defined conditions requires specific plating densities for optimal hematoendothelial differentiation. Human ESCs need to be plated around 7,500 cells $/ \mathrm{cm}^{2}$. Harvesting, counting, and seeding of hPSCs on the Ten-C or CollV plate should be performed quickly as singularized hPSCs do not survive well until mixed with rock inhibitor and plated.

12. OP9-DLL4 cells should be split every 3-4 days for maintenance/expansion. Proper maintenance of OP9-DLL4 is most critical step for T cell differentiation. Our lab strictly uses the defined FBS without heat inactivation. Heat inactivation does not benefit culture but rather results in a higher adipogenic effect on OP9/OP9-DLL4.

13. We have found that different lots of HyClone-defined FBS provide relatively consistent effects on OP9-DLL4 maintenance and T cell differentiation without substantial adipogenesis. Results from other suppliers are more variable.

14. OP9-DLL4 cells should not get overconfluent as it reduces the T cell differentiation ability. Hence, it is always important to perform passages the cells before they get confluent, which is typically 3-4 days when cultured in an appropriate serum.

15. Cell density in initial HPs/OP9-DLL4 coculture may affect downstream differentiation. A very high number of HPs can cause rapid development of NK cells which could lead to rapid killing of OP9-DLL4 feeders and compromise T cell development.

16. Differentiating HPs on OP9-DLL4 may reach high density by the second week or earlier. If this occurs, split the cells onto fresh OP9-DLL4 plates. Around $1 \times 10^{5} \mathrm{~T}$ cells progenitors/well of 6 well plates are ideal for differentiation during the second or subsequent weeks. High density cultures may result in reduced T cell differentiation efficiency.

17. There is no strict rule of weekly passaging during $T$ cell differentiation. If the differentiating cells appear highly dense, then it is advised to subculture the cells as soon as possible onto fresh OP9-DLL4.

18. Total number of $T$ cells generated from $1 \times 10^{4} \mathrm{CD}_{4} 3^{+}$cells obtained from iETS1-hESCs in doxycycline treated and untreated conditions are much higher in comparison to other systems, cell types and sources (Figure 5). 


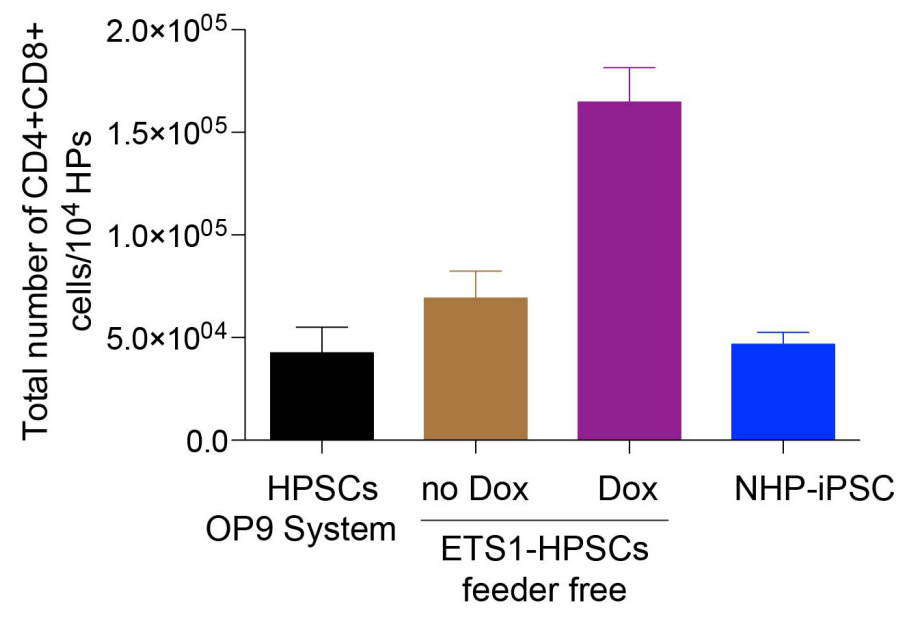

Figure 5. Bar graph shows the total number of T cells generated from $10^{4} \mathrm{HPs}$ obtained from iETS1-hESCs in doxycycline treated and untreated conditions, wild-type NHP iPSCs and hPSCs. Total number of T cells generated is higher from iETS1-PSC in comparison to total HPs generated from different methods and different sources.

\section{$\underline{\text { Recipes }}$}

1. Human PSC growth Medium (Table 2)

a. Prepare stocks of DMEM/F-12 from powder according to the manufacturer's instructions

b. Sterilize filter using a $0.22 \mu \mathrm{m}$ membrane filter and store for up to 2 months at $2-8^{\circ} \mathrm{C}$

c. Use this basal media to prepare a complete $500 \mathrm{ml}$ of hESC culture medium

Table 2. Human PSC growth medium

\begin{tabular}{lll}
\hline Composition & Volume $(500 \mathrm{ml})$ & Final concentration \\
\hline DMEM/F-12 & $390 \mathrm{ml}$ & \\
KO serum replacement & $100 \mathrm{ml}$ & $20 \%$ \\
NEAA solution $(100 \mathrm{x} ; 10 \mathrm{mM})$ & $5 \mathrm{ml}$ & $100 \mu \mathrm{M}$ \\
L-glutamine/2-mercaptoethanol $(100 \mathrm{mM})$ & $5 \mathrm{ml}$ & $1 \mathrm{mM}$ \\
Basic FGF-2 (100 $\mu \mathrm{g} / \mathrm{ml})$ & $10 \mu \mathrm{rl}$ & $4 \mathrm{ng} / \mathrm{ml}$ \\
\hline
\end{tabular}

2. MEF growth medium (Table 3)
a. Prepare stocks of DMEM from powder according to the manufacturer's instructions
b. Sterilize filter using a $0.22 \mu \mathrm{m}$ membrane filter and store for up to 2 months at $2-8^{\circ} \mathrm{C}$
c. Prepare $500 \mathrm{ml}$ of MEF growth medium by using stocks of DMEM and store up to 3 weeks at $2-8{ }^{\circ} \mathrm{C}$ 
Please cite this article as: Kumar et. al., (2020). Generation of T cells from Human and Nonhuman Primate Pluripotent Stem Cells,Bio-protocol 10 (13):

Table 3. MEF growth medium

\begin{tabular}{lll}
\hline Composition & Volume $(500 \mathrm{ml})$ & Final concentration \\
\hline DMEM & $445 \mathrm{ml}$ & \\
FBS & $50 \mathrm{ml}$ & $10 \%$ \\
NEAA solution & $5 \mathrm{ml}$ & $100 \mu \mathrm{M}$ \\
$(100 \times, 10 \mathrm{mM})$ & & \\
\hline
\end{tabular}

3. NHP-PSC Medium (Table 4)

Use primate ESC medium from Reprocell to make $500 \mathrm{ml}$ of NHP-PSCs medium

Table 4. NHP-PSC medium

\begin{tabular}{lll}
\hline Composition & Volume $(500 \mathrm{ml})$ & Final concentration \\
\hline Primate ES cell Medium & $500 \mathrm{ml}$ & \\
Basic FGF2 & $20 \mu \mathrm{l}$ & $4 \mathrm{ng} / \mathrm{ml}$ \\
\hline
\end{tabular}

4. Mouse OP9/OP9-DLL4 bone marrow stromal cell culture medium (Table 5)

a. Prepare stocks of fresh a-MEM from powder according to the manufacturer's instructions

b. Sterilize by filtration using a $0.22-\mu \mathrm{m}$ membrane filter and store for up to 2 months at $2-8^{\circ} \mathrm{C}$

c. Use this basal media to prepare a complete $500 \mathrm{ml}$ of OP9/OP9-DLL4 culture medium

Table 5. OP9/OP9-DLL4 medium

\begin{tabular}{lll}
\hline Composition & Volume & Final concentration \\
\hline a-MEM & $400 \mathrm{ml}$ & \\
Hyclone FBS & $100 \mathrm{ml}$ & $20 \%$ \\
\hline
\end{tabular}

5. Human hematopoietic differentiation (OP9 coculture system) medium (Table 6)

Use $\alpha$-MEM basal medium to prepare $500 \mathrm{ml}$ of human hematopoietic differentiation medium

Table 6. OP9 coculture medium for differentiation of hPSCs

\begin{tabular}{lll}
\hline Composition & Volume & Final concentration \\
\hline a-MEM & $400 \mathrm{ml}$ & \\
Hyclone FBS & $100 \mathrm{ml}$ & $20 \%$ \\
MTG & $500 \mu \mathrm{l}$ & $100 \mu \mathrm{M}$ \\
Ascorbic acid & $500 \mu \mathrm{ll}$ & $50 \mathrm{mg} / \mathrm{ml}$ \\
\hline
\end{tabular}

6. NHP differentiation medium (Table 7)

Use $\alpha$-MEM basal medium to prepare $500 \mathrm{ml}$ of primate differentiation medium 
Table 7. NHP-PSC differentiation medium

\begin{tabular}{lll}
\hline Composition & Volume & Final concentration \\
\hline a-MEM & $450 \mathrm{ml}$ & \\
Hyclone FBS & $50 \mathrm{ml}$ & $10 \%$ \\
2-mercaptoethanol & $1.76 \mu \mathrm{l}$ & $50 \mu \mathrm{M}$ \\
\hline
\end{tabular}

7. IF4S Stock Medium (Table 8)

Prepare 10x IF4S basal media by using the following components

Table 8. IF4S stock medium

\begin{tabular}{lll}
\hline Composition & Volume & Stock concentration \\
\hline IMDM & $1 \mathrm{Lx} 5$ & $5 \mathrm{x}$ \\
$\mathrm{F} 12$ & $1 \mathrm{Lx} 5$ & $5 \mathrm{x}$ \\
$\mathrm{ddH}_{2} \mathrm{O}$ & $900 \mathrm{ml}$ & \\
Sodium Bicarbonate & $21 \mathrm{~g}$ & $21 \mathrm{~g} / \mathrm{L}$ \\
Ascorbic acid & $640 \mathrm{mg}$ & $640 \mathrm{mg} / \mathrm{L}$ \\
MTG & $400 \mu \mathrm{l}$ & $400 \mu \mathrm{L} / \mathrm{L}$ \\
Sodium Selenite & $120 \mu \mathrm{l}$ & $140 \mu \mathrm{g} / \mathrm{L}$ \\
CDLC & $20 \mathrm{ml}$ & $2 \mathrm{x}$ \\
\hline
\end{tabular}

8. 5x PVA Stock Solution (Table 9)

a. Autoclave $1 \mathrm{LddH} \mathrm{H}_{2} \mathrm{O}$ with a stir bar. Once finished, place it on a heated magnetic stirrer

b. Slowly add PVA in $2.5 \mathrm{~g}$ increments

c. Make sure the PVA is dissolved before adding more and that it does not aggregate in the hot $\mathrm{ddH}_{2} \mathrm{O}$

d. Once all of the PVA is added, continue stirring overnight at room temperature

e. Autoclave again the next day to sterilize

f. Store at room temperature up to 1 year

Table 9. PVA stock solution

\begin{tabular}{lll}
\hline Composition & Volume & Final concentration \\
\hline PVA & $50 \mathrm{~g}$ & $50 \mathrm{~g} / \mathrm{L}$ \\
$\mathrm{ddH}_{2} \mathrm{O}$ & $1 \mathrm{~L}$ & \\
\hline
\end{tabular}

9. IF9S Medium (Table 10)

a. Prepare $500 \mathrm{ml}$ of IF9S medium for human hematopoietic differentiation media by using the IF4S medium

b. Add the following component without PVA into IF4S and sterilize by filtration using a 0.22 $\mu \mathrm{m}$ membrane filter 
c. After filtration add $100 \mathrm{ml}$ of $5 x$ PVA

Table 10. IF9S medium

\begin{tabular}{lll}
\hline Composition & Volume & Stock concentration \\
\hline IF4S (10x) & $50 \mathrm{ml}$ & \\
ddH $_{2} \mathrm{O}$ & $340 \mathrm{ml}$ & \\
PVA & $100 \mathrm{ml}$ & $10 \mathrm{~g} / \mathrm{L}$ \\
GlutaMax (100x) & $5 \mathrm{ml}$ & $1 \mathrm{x}$ \\
NEAA(100x) & $5 \mathrm{ml}$ & $1 \mathrm{x}$ \\
Holo-transferrin & $500 \mathrm{\mu l}$ & $10.6 \mathrm{mg} / \mathrm{L}$ \\
Insulin & $1 \mathrm{ml}$ & $20 \mathrm{mg} / \mathrm{L}$ \\
\hline
\end{tabular}

10. T lymphoid differentiation medium (Table 11)

a. Use a-MEM basal medium to prepare T lymphoid differentiation medium

b. To prepare $100 \mathrm{ml}$ of $\mathrm{T}$ lymphoid differentiation medium, add the following component to $\alpha-$ MEM basal medium and sterilize by filtration using a $0.22 \mu \mathrm{m}$ membrane filter

c. Alternatively, add SCF $(10 \mathrm{ng} / \mathrm{ml}), \mathrm{IL}-7(5 \mathrm{ng} / \mathrm{ml})$ and FLT3-L $(5 \mathrm{ng} / \mathrm{ml})$ to the OP9/OP9-DLL4 culture medium to make $\mathrm{T}$ lymphoid differentiation medium

Table 11. T lymphoid differentiation medium

\begin{tabular}{lll}
\hline Composition & Volume & Final concentration \\
\hline a-MEM & $80 \mathrm{ml}$ & \\
Hyclone FBS & $20 \mathrm{ml}$ & $20 \%$ \\
SCF-1 & $10 \mu \mathrm{l}$ & $10 \mathrm{ng} / \mathrm{ml}$ \\
IL7 & $5 \mu \mathrm{l}$ & $5 \mathrm{ng} / \mathrm{ml}$ \\
FLT3L & $5 \mu \mathrm{l}$ & $5 \mathrm{ng} / \mathrm{ml}$ \\
\hline
\end{tabular}

11. HBS saline solution $(2 x)$
a. Prepare 100 mlof $2 x$ HBS solution by adding HEPES (50 mM), $\mathrm{KCl}(10 \mathrm{mM})$, dextrose (12 $\mathrm{mM}), \mathrm{NaCl}(280 \mathrm{mM})$ and $\mathrm{Na}_{2} \mathrm{HPO}_{4}(1.5 \mathrm{mM})$
b. Adjust the $\mathrm{pH}$ to exactly $7.05-7.08$
c. Filter the solution through $0.2 \mu \mathrm{m}$ filter

12. $\mathrm{CaCl}_{2}$ solution (2 M)
a. Prepare $50 \mathrm{ml}$ of $2 \mathrm{M}$ of $\mathrm{CaCl}_{2}$ solution by dissolving $14.702 \mathrm{~g}$ of CaCl 2 in $50 \mathrm{ml}$ of distilled water
b. Filter sterilize the solution using $0.2 \mu \mathrm{m}$ filter

13. Gelatin solution $[0.1 \%(\mathrm{wt} / \mathrm{vol})]$
a. Add $500 \mathrm{mg}$ of gelatin to $500 \mathrm{ml}$ of endotoxin-free reagent-grade distilled water
b. Solubilize and sterilize by autoclaving for $20 \mathrm{~min}$ at $121^{\circ} \mathrm{C}$ 
C. Store the solution at $4{ }^{\circ} \mathrm{C}$ for up to 6 months

14. Magnetic cells sorting (MACS) buffer (Table 12)

a. Prepare $500 \mathrm{ml}$ of MACS buffer as shown

b. Sterilize MACS buffer by filtration using a $0.22 \mu \mathrm{m}$ membrane filter and keep at $2-8{ }^{\circ} \mathrm{C}$ for up to 6 months

Table 12. MACS buffer

\begin{tabular}{lll}
\hline Composition & Volume $(500 \mathrm{ml})$ & Final concentration \\
\hline DPBS & $473 \mathrm{ml}$ & \\
FBS & $25 \mathrm{ml}$ & $5 \%$ \\
$\operatorname{EDTA}(0.5 \mathrm{M})$ & $2 \mathrm{ml}$ & $2 \mathrm{mM}$ \\
\hline
\end{tabular}

15. Flow cytometry buffer (FACS) buffer (Table 13)

a. Prepare $500 \mathrm{ml}$ of FACS buffer as shown

b. Filtrate the buffer using a $0.22 \mu \mathrm{m}$ membrane filter and store at $2-8{ }^{\circ} \mathrm{C}$ for up to 6 months

Table 13. FACS buffer

\begin{tabular}{lll}
\hline Composition & Volume $(500 \mathrm{ml})$ & Final concentration \\
\hline DPBS & $488 \mathrm{ml}$ & \\
FBS & $10 \mathrm{ml}$ & $2 \%$ \\
EDTA $(0.5 \mathrm{M})$ & $2 \mathrm{ml}$ & $2 \mathrm{mM}$ \\
Sodium azide & $0.25 \mathrm{~g}$ & $0.05 \%$ \\
\hline
\end{tabular}

16. Reconstitution of cytokines

a. All the cytokines were reconstituted and stored in $-80{ }^{\circ} \mathrm{C}$ according to manufacturer's recommendations

b. Briefly, centrifuge the vials at maximum speed for $1 \mathrm{~min}$ to precipitate lyophilized pellets before opening vials

c. Dilute with $0.1 \%$ BSA/PBS solution for working concentration and store at $-80{ }^{\circ} \mathrm{C}$ until needed for use

17. Collagenase solution $(1 \mathrm{mg} / \mathrm{ml})$

a. Add $50 \mathrm{mg}$ of collagenase to $50 \mathrm{ml}$ of DMEM/F-12 basal medium and sterilize the solution by filtration using a $0.22 \mu \mathrm{m}$ membrane filter

b. Keep the solution at $2-8^{\circ} \mathrm{C}$ and use it for up to 1 week

18. Doxycycline $(1 \mathrm{mg} / \mathrm{ml})$

a. Dissolve doxycycline to $1 \mathrm{mg} / \mathrm{ml}$ in $\mathrm{dd}_{2} \mathrm{O}$

b. Prepare $100 \mu \mathrm{l}$ aliquotes in amber $1.5-\mathrm{ml}$ microcentrifuge tubes for light protection and store up to 5 days at $4{ }^{\circ} \mathrm{C}$ or 2 months at $20^{\circ} \mathrm{C}$ 


\section{Acknowledgments}

We thank many members of the Slukvin Lab, especially Drs. Maxim Vidyanik and Kyung Dal Choi, who over the years have helped to develop and optimized human hematopoietic differentiation on the OP9 coculture system. We thank Dr. Toru Nakano (Osaka University, Osaka, Japan) for providing OP9 cells, Mitch Probasco (Morgridge Institute for Research) for cell sorting, and Mathew Raymond (Wisconsin National Primate Research Center) for editorial assistance as well as for cell sorting. This work was supported by funds from the National Institute of Health (R01 HL132891, RO1 HL142665, R24 OD021322, and P51 OD011106).

This protocol was adapted from previous work Vodyanik et al., 2006; Uenishi et al., 2014; D'Souza et al., 2016 Kumar et al., 2019b; Park et al., 2018b.

\section{Competing interests}

The authors declare no conflicts of interest.

\section{References}

1. Adams, E. J., Cooper, S. and Parham, P. (2001). A novel, nonclassical MHC class I molecule specific to the common chimpanzee. J Immunol 167(7): 3858-3869.

2. Bimber, B. N., Moreland, A. J., Wiseman, R. W., Hughes, A. L. and O'Connor, D. H. (2008). Complete characterization of killer lg-like receptor (KIR) haplotypes in Mauritian cynomolgus macaques: novel insights into nonhuman primate KIR gene content and organization. J Immunol 181(9): 6301-6308.

3. Choi, K. D., Vodyanik, M. A. and Slukvin, II (2009a). Generation of mature human myelomonocytic cells through expansion and differentiation of pluripotent stem cell-derived linCD34 ${ }^{+}$CD43 ${ }^{+}$CD45 ${ }^{+}$progenitors. J Clin Invest 119(9): 2818-2829.

4. Choi, K. D., Vodyanik, M. A., Togarrati, P. P., Suknuntha, K., Kumar, A., Samarjeet, F., Probasco, M. D., Tian, S., Stewart, R., Thomson, J. A. and Slukvin, II (2012). Identification of the hemogenic endothelial progenitor and its direct precursor in human pluripotent stem cell differentiation cultures. Cell Rep 2(3): 553-567.

5. Choi, K. D., Yu, J., Smuga-Otto, K., Salvagiotto, G., Rehrauer, W., Vodyanik, M., Thomson, J. and Slukvin, I. (2009b). Hematopoietic and endothelial differentiation of human induced pluripotent stem cells. Stem Cells 27(3): 559-567.

6. D'Souza, S. S., Maufort, J., Kumar, A., Zhang, J., Smuga-Otto, K., Thomson, J. A. and Slukvin, II (2016). GSK3beta inhibition promotes efficient myeloid and lymphoid hematopoiesis from nonhuman primate-induced pluripotent stem cells. Stem Cell Reports 6(2): 243-256.

7. Houot, R., Schultz, L. M., Marabelle, A. and Kohrt, H. (2015). T-cell-based immunotherapy: adoptive cell transfer and checkpoint inhibition. Cancer Immunol Res 3(10): 1115-1122. 
8. June, C. H., O'Connor, R. S., Kawalekar, O. U., Ghassemi, S. and Milone, M. C. (2018). $\underline{\text { CAR }}$ T cell immunotherapy for human cancer. Science 359(6382): 1361-1365.

9. Jung, H. S., Uenishi, G., Kumar, A., Park, M. A., Raymond, M., Fink, D., McLeod, E. and Slukvin, I. (2016). A human VE-cadherin-tdTomato and CD43-green fluorescent protein dual reporter cell line for study endothelial to hematopoietic transition. Stem Cell Res 17(2): 401-405.

10. Kaneko, S. (2016). In vitro generation of antigen-specific T cells from induced pluripotent stem cells of antigen-specific T cell origin. Methods Mol Biol 1393: 67-73.

11. Kumar, A., D'Souza, S. S. and Thakur, A. S. (2019a). Understanding the journey of human hematopoietic stem cell development. Stem Cells Int 2019: 2141475.

12. Kumar, A., Lee, J. H., Suknuntha, K., D'Souza, S. S., Thakur, A. S. and Slukvin, II (2019b). NOTCH activation at the hematovascular mesoderm stage facilitates efficient generation of $T$ cells with high proliferation potential from human pluripotent stem cells. J Immunol 202(3): 770776.

13. Minagawa, A. and Kaneko, S. (2014). Rise of iPSCs as a cell source for adoptive immunotherapy. Hum Cell 27(2): 47-50.

14. Nishimura, T., Kaneko, S., Kawana-Tachikawa, A., Tajima, Y., Goto, H., Zhu, D., NakayamaHosoya, K., Iriguchi, S., Uemura, Y., Shimizu, T., Takayama, N., Yamada, D., Nishimura, K., Ohtaka, M., Watanabe, N., Takahashi, S., Iwamoto, A., Koseki, H., Nakanishi, M., Eto, K. and Nakauchi, H. (2013). Generation of rejuvenated antigen-specific $T$ cells by reprogramming to pluripotency and redifferentiation. Cell Stem Cell 12(1): 114-126.

15. Parham, P., Abi-Rached, L., Matevosyan, L., Moesta, A. K., Norman, P. J., Older Aguilar, A. M. and Guethlein, L. A. (2010). Primate-specific regulation of natural killer cells. J Med Primatol 39(4): 194-212.

16. Park, M. A., Jung, H. S. and Slukvin, I. (2018a). Genetic engineering of human pluripotent stem cells using PiggyBac transposon system. Curr Protoc Stem Cell Biol 47(1): e63.

17. Park, M. A., Kumar, A., Jung, H. S., Uenishi, G., Moskvin, O. V., Thomson, J. A. and Slukvin, II (2018b). Activation of the arterial program drives development of definitive hemogenic endothelium with lymphoid potential. Cell Rep 23(8): 2467-2481.

18. Riviere, I. and Sadelain, M. (2017). Chimeric antigen receptors: a cell and gene therapy perspective. Mol Ther 25(5): 1117-1124.

19. Themeli, M., Kloss, C. C., Ciriello, G., Fedorov, V. D., Perna, F., Gonen, M. and Sadelain, M. (2013). Generation of tumor-targeted human T lymphocytes from induced pluripotent stem cells for cancer therapy. Nat Biotechnol 31(10): 928-933.

20. Uenishi, G., Theisen, D., Lee, J. H., Kumar, A., Raymond, M., Vodyanik, M., Swanson, S., Stewart, R., Thomson, J. and Slukvin, I. (2014). Tenascin C promotes hematoendothelial development and $\mathrm{T}$ lymphoid commitment from human pluripotent stem cells in chemically defined conditions. Stem Cell Reports 3(6): 1073-1084.

21. Uenishi, G. I., Jung, H. S., Kumar, A., Park, M. A., Hadland, B., McLeod, E., Raymond, M., Moskvin, O. V., Zimmerman, C., Theisen, D. J., Swanson, S., Tamplin, O., Zon, L., Thomson, 
J. A., Bernstein, I. D. and Slukvin, I. I. (2018). $\mathrm{NOTCH}$ signaling specifies arterial-type definitive hemogenic Endothelium from human pluripotent stem cells. Nature Commun 9(1):1828.

22. Vizcardo, R., Masuda, K., Yamada, D., Ikawa, T., Shimizu, K., Fujii, S., Koseki, H. and Kawamoto, H. (2013). Regeneration of human tumor antigen-specific T cells from iPSCs derived from mature $\mathrm{CD}^{+} \mathrm{T}$ cells. Cell Stem Cell 12(1): 31-36.

23. Vodyanik, M. A., Bork, J. A., Thomson, J. A. and Slukvin, II (2005). Human embryonic stem cellderived $\mathrm{CD} 34^{+}$cells: efficient production in the coculture with OP9 stromal cells and analysis of Iymphohematopoietic potential. Blood 105(2): 617-626.

24. Vodyanik, M. A. and Slukvin, II (2007). Hematoendothelial differentiation of human embryonic stem cells. Curr Protoc Cell Biol Chapter 23: Unit 2326.

25. Vodyanik, M. A., Thomson, J. A. and Slukvin, II (2006). Leukosialin (CD43) defines hematopoietic progenitors in human embryonic stem cell differentiation cultures. Blood 108(6): 2095-2105. 